prepared on the occurrence of the first vacancy in the chair of astrophysics to contribute a sum of ten thousand pounds towards the permanent endowment of the chair, provided that the University is willing to undertake to supplement this sum by such further endowment either of principal or of income as will raise the emoluments of the chair thenceforward to 8ool. a year."

Mr. C. Hankins, forester to Earl. Cadogan, has been appointed adviser in forestry. He will be under the supervision of the reader in forestry, under whose responsibility all working plans and proposals of a general nature will be issued.

OxFord.-The proposal to allocate a site in the University Park for the erection of an engineering laboratory has been dropped, it being understood that a suitable piece of ground will be available for this purpose without encroaching on the open space which adds so freatly to the amenities of Oxford.

Mr. W. JAMEs Thomas, of Ynyshir, has increased his gift of 10,000 guineas to the Lniversity College of South Wales and Monmouthshire to 12,75ol. in order to cover the full cost of erecting a medical s.hoo!.

A LEADING article in The Chemical World on the Oxford University Labaratory directs attention to the remarkable developments that are in progress in the teaching of chemistry in the Universities of Oxford and Cambridge. Since the institution of the new régime at Cambridge, four years ago, 'I 50 original communications have been published from the chemical laboratory of that University, a record that is probably unequalled by any laboratory in this country or elsewhere. In the same period the number of graduate and post-graduate students in the laboratories has more than doubled. There can be little doubt that similar developments are to be anticipated at Oxford, following the recent election of Prof. W. H. Perkin to the chair of chemistry.

THE governing body of the University of Wisconsin has decided, says Science, to ask the State legislature, now in session, for $200,000 l$, to be granted in sums of $50,000 l$. a year for four years, in order to provide and equip further accommodation for men students. The continuance of the present appropriation of $60,000 l$. a year for the construction and equipping of academic buildings will also be requested. For the further development of university extension work, an increase of $5000 l$. a year is desired. Owing to the reduction in the assessed valuation of personal property, resulting from the adoption of the income tax in Wisconsin, the University's fund for current expenses has this year fallen below the amount anticipated. The governors, therefore, have requested that the sum of $18,500 l$. be appropriated to make up this year's decrease, that 35 ,omol. be provided for next year's decrease, and $45,000 l$. for the following year's decrease.

VERY important developments are now taking place in the Royal (Dick) Veterinary College in Edinburgh. Not the least important is the removal from the present limited quarters to what will in a year or two be a fine addition to the many colleges which adorn the city. To make room for the new buildings, some quaint cottages of a bygone epoch will have to be removed. These are in what is known as Summerhall Square, which hes to the east of the East Meadows in the southern part of Edinburgh. The main frontage of the buildings will face west, and in the rear the clinical department will be housed in buildings quite distinct from those devoted to teaching and administration. The various faboratories and class-rooms will be equipped with the best modern appliances for the study of the diseases and treatment of domestic animals. Another important development is the establishment of a degree in veterinary science in the University of Edinburgh. The regulations require the student to attend certain of the more purely scientific courses in the Liniversity, but the more technical part of the training is given in the Royal Veterinary College. Though no nearer to the University than the present college building, the new buildings will be much more conveniently situated, and the practical affiliation of the two institutions will be more thoroughly effected. It is expected that the new college will be ready for use in October, rgi4.

ON February 13 a brilliant University function was held in the Library Hall of Edinburgh University, when Sir William 'Turner's portrait was presented by the subscribers to the University. Mr. A. J. Balfour, M.P., the Chancellor of the University, presided, and received the portrait from Sir Robert Findlay, M.P., who presented it in the name of the many subscribers. Sir Robert Findlay, himself an old pupil of Sir William's, spoke of the sixty years' service which Sir William had rendered to the University, first as assistant to Prof. Goodsir, then as professor of anatomy, and finally as principal of the University. As Sir Robert made the presentation, the curtain was drawn aside and revealed a striking and happy portraiture of the veteran principal, by the hand of Sir James Guthrie, president of the Royal Scottish Academy. Mr. Balfour, in his remarks, dwelt on the remarkable developments which had taken place during the last fifty years in university life in Edinburgh. In making their University keep up with modern needs, Sir William Turner was the man who above all others had taken the greatest share in this development. He combined in an unusual way the qualities of a great teacher and a great administrator. Lord Provost Inches having expressed the high appreciation which the Corporation had for Sir William, whom a few years since they had enrolled as a burgess of their city. Sir William Turner, after thanking his many friends and old students for their great kindness, gave some interesting reminiscences of the early days in which he began his life in Edinburgh. Although he could not claim Edinburgh as his birthplace, he was sure no one could love the old city better than he did, or could have a higher regard for its historic associations and its peculiar and indefinable charm. The ceremony they had been engaged in would remain in his mind, during the brief period that he might look to for a continuance of life, as a mark of confidence and esteem from his colleagues, students, and friends.

\section{SOCIETIES AND ACADEMIES}

\section{LoNDon:}

Royal Society, February 13.-Sir Archibald Geikie, K.C.B., president, in the chair.-Prof. R. A. Sampson : A Cassegrain reflector with corrected field. The purpose of this memoir is to discover an appliance which shall correct in a practical manner the faults of the field of a Cassegrain telescope while leaving unimpaired its characteristic features of great focal length, convenient position of the observer and achromatism. It is shown in agreement with the investigation of Schwarzschild that two mirrors alone cannot correct the field without introducing impracticable curves or sacrificing the general design. A system of lenses is investigated which shal effect the purpose. Three kenses is the least number which can satisfy the two conditions of achromatism.

NO. 2260 , VOL. 90] 
Achromatism for all colours is preserved completely by making all the lenses of the same glass. The first of these lenses is a meniscus silvered at the back, and besides adjusting the ackromatism of the other two, serves to reverse the direction of the ray. The other two form a pair of nearly equal but opposite focal lengths and intercept the outcoming beam. By a proper distribution of curvatures between their faces they introduce correcting aberrations. The resulting field is completely corrected for colour, spherical aherration, coma, and curvature of the field.-Prof. H. E. Armstrong and Dr. J. V. Eyre: Studies of the processes operative in solutions. XXV., The influence of non-electrolytes on solubility. The nature of the processes of dissolution and precipitation.-E. E. Walker: Studies of the processes operative in solutions. XXVI., The disturbance of the equilibrium in solutions of fructose by salts and by non-electrolytes. -J. Chadwick and A. S. Russell : The excitation of $\gamma$ rays by the $\alpha$ rays of ionium and radiothorism. The work on the excitation of $\gamma$ rays by $\alpha$ rays, shown first by Chadwick in the case of the a rays of radium $\mathrm{C}$, has been extended to ionium. A preparation of ionium and thorium equal in $\alpha$-ray activity to $3 \mathrm{mgr}$. of radium, after purification from all radio-active bodies which emit $\beta$ and $\gamma$ rays, was found to emit a small but easily detectable amount of $\gamma$ radiation. This radiation is shown to be excited by the $\alpha$ rays, either in the ionium itself, or in the thorium with which it is mixed. It $s$ a mixture of three types of radiation differing widely in penetrating power.Prof. W. E. Dalby : Load-extension diagrams taken with the optical load-extension indicator. In this paper further experiments with the indicator are described. The optical load-extension indicator itself was fully described and illustrated in a paper read on March 7, I0,12. Load-extension diagrams obtained from phosphor-bronze, gun-metal, and brass are shown, together with photomicrographs taken from the specimens tested. The chemical analyses of the metals are given in each case. The effect of annealing brass rod is brought out by comparing the loadextension diagrams of an annealed and an unannealed specimen and by making a similar comparison of the corresponding photomicrographs of the structure of the material. The physical effect of annealing is to produce a state in which the load-extension curve approaches the shape given by copper, and bears little resemblance to the curve obtained from the same material in an unannealed state.

Zoological Society, February 4.- Sir John Rose Bradford, K.C.M.G., F.R.S., vice-president, in the chair. -Dr. F. E. Beddard: The anatomy and systematic arrangement of the Cestoidea. The paper dealt with a number of new species of Ichthyotænia and Ophidotrenia obtained from the gut of serpents that had died in the gardens.-H. G. Plimmer : Report on the deaths which occurred in the society's gardens during the past year, together with a list of the blood parasites found during the same period. An examination had been made of the blood of every animal that had died, with the result that parasites had been discovered in I 40 cases, and in eighty of these for the first time. -H. L. Hawkins : The anterior ambulacrum of Echinocardium cordatum and the origin of compound plates in the Echinoidea. A new method was described of exposing sutures in recent Echinoids suitable for photographic purposes, the process combining staining with etching, and the description of the complex plating of ambulacrum III. in $E$. cordatum. The origin of ambulacrum "plate-crushing," founded on a brief survey of the phenomenon in all groups of Echinoids, was discussed. Mechanical growthpressure was regarded as the cause, with the growth of tubercles (Lambert's hypothesis) as a secondary and merely modifying agent.-G. P. Farran : Plankton from Christmas Island, Indian Ocean. II., Copepoda of the genera Oithona and Paroithona. This collection, made in 1908 by Sir John Murray and Dr. C. W. Andrews, contained eleven species of Oithona and one of Paroithona, or rather more than half the known species, the total number of known species of Oithona being eighteen and of Paroithona two. This indicated the great richness in species of collections made in tropical waters. Seven of the species of Oithona and the one Paroithona appeared to be new to science.

Linnean Society, February 6.-Prof. E. B. Poulton, F.R.S., president, in the chair.-A. W. Sutton : Results of crosses between a wild pea from Palestine, presumably Pisum humile, Boiss and Noé, and cultivated forms.--Miss Bancroft: The structure of Rhexoxylon africanum. A fossil stem described by Dr. A. W. Rogers as probably coming from the Karroo rocks of Cape Colony, indicates affinities with the Medulloseæ of later. Palæozoic age.-Di. R. Verity : Revision of the Linnean types of Palæarctic Rhopalocira.

Mathematical Society, February I3.-Prof. A. E. H. Love, president, in the chair.-T. C. Lewis: Figures in $n$-dimensional space analogous to orthocentric tetrahedra.-J. E. Littlewood : A property of the $\zeta$-function. - G. H. Hardy : The summability of a Fourier's series. -G. H. Hardy and J. E. Littlewood: Trigonometrical series which converge nowhere or almost nowhere.H. Bohr: A theorem concerning power series.-P. J. Heawood: A graphical demonstration of the fundamental properties of quadratic residues.-J. B. Holt : The irreducibility of Legendre's polynomials (third paper).-W. H. Young: The mode of oscillation of a Fourier series and its allied series.-H. T. H. Piaggio: Some non-primary perpetuant syzygies of the second kind.

Literary and Philosophical Society, February 4.--Prof. F. E. Weiss, president, in the chair.-D. Thoday : A capillary eudiometric apparatus for analysing small volumes of air. Results of experiments relating to the exchange of gases between plants and the atmosphere.-W. B. Brierley: The structure and lifehistory of Sphaeria lemaneae. The author traced the origin and development of the vegetative and reproductive organs of Sphaeria lemaneae, a fungus inhabiting sexual filaments of Lemanea. The relations obtaining between the host and parasite were elucidated, and the morphological structure and cytology of the fungus shown to be in general agreement with previous knowledge of Pyrenomycetous fungi. The accepted systematic position of Sphaeria lemaneae was questioned.

\section{PARIS.}

Academy of Sciences, February ro.-M. F. Guyon in the chair.--Pierre Duhem: Two fundamental inequalities of thermodynamics.-Paul Sabatier and M. Murat : The direct addition of hydrogen to the phenylacetic esters : the preparation of cyclohexylacetic acid. This reaction requires a large excess of hydrogen in presence of a very active nickel, maintained at $180^{\circ} \mathrm{C}$. The yield is quantitative, no loss occurring through secondary reactions. The properties of cyclohexylacetic acid and of five of its esters are described.Charles Depéret: Observations on the Pliocene and Quaternary geological history of the gulf and isthmus of Corinth.-Hugo de. Vries was elected a correspondant of the academy in the section of botany, in the place of M. Schwendener, elected
foreign associate.-Mlle. S. Tillinger: The determination of the growth of functions defined by a Taylor's NO. 2260 , VOL. 90] 
series.-J. Le Roux: The determination of the harmonic functions.-Th. De Donder: A theorem of Jacobi.-Henri Villat : The determination of problems of hydrodynamics relating to the resistance of fluids. -M. Gernez: Construction and use of maps for orthodromic navigation on planes tangent to the poles.L. Crussard: The deformation of waves in gases and on finite interferences.-Carl Störmer: An important problem in cosmical physics.-Albert Turpain : Recording the Hertzian time signals. The possibility of recording directly and determining to a hundredth of a second the Eiffel Tower time signals. A description of the results obtained by a photographic recorder, by means of which the beats of a chronometer and the wireless time signals are registered on the same sheet. -Edm. van Aubel: The latent heat of vaporisation of metals. Utilising the experimental data of Wehnelt and Musceleanu for the latent heats of vaporisation of mercury, cadmium, zinc, and bismuth, Trouton's law is shown to hold for these metals, the constant varying only between $19 \cdot 36$ and $20 \cdot 2 .-A$. Guillet and M. Aubert : Electric losses in the system plane-sphere-atmospheric air. The coefficient of asymmetry and its measurement. $-\mathrm{V}$. Crémieu : A new idiostatic voltmeter. The voltmeter is claimed to be very sensitive, not damaged by excessive voltages, and not so fragile as the gold-leaf electroscope.-Jean Becquerel, L. Matout, and Mlle. W. Wright: Hall's phenomenon in antimony. The Hall effect for antimony increases as the temperature of the metal is lowered, and depends on the position of the axes of the crystal in the magnetic field. The electromotive force is not always proportional to the strength of the magnetic field.-William Duane and Otto Scheuer : The decomposition of water by the a rays. At $-183^{\circ} \mathrm{C}$. the hydrogen and oxygen evolved are in molecular proportion; in the liquid state the hydrogen is in excess, some hydrogen peroxide being also formed. When steam is decomposed by the $\alpha$ rays hydrogen is also in excess.-Daniel Berthelot and Henry Gaudechon: The inversion of saccharose by the ultra-violet rays. A criticism of recent work by other workers in this subject.-Marcel Godchot and Felix Taboury : The catalytic hydrogenation of camphorone; some new cyclopentane hydrocarbons. Camphorone, treated with hvdrogen and reduced nickel at $130^{\circ} \mathrm{C}$., gives quantitatively dihydrocamphorone. At $280^{\circ} \mathrm{C}$. the product is methyl-I-iso-propyl-3-cyclopentane.-A. Duffour: An interesting case of dimorphism. Benzylvanillic alcohol crystallises in monoclinic or triclinic crystals, according to its method of preparation. The triclinic modification is stable at the melting point Robert Mirande : The presence of callose in the membrane of some marine Algæ.-C. M. Bret: The existence in western Africa of two stable forms of Hevea brasiliensis presenting a different aptitude in the production of latex. The two forms can be distinguished by the anatomical study of the base of the petiolules, the most vigorous plant being the poorest in latex. H. Bierry and Mlle. Lucie Fandard: Adrenaline and glycemia. The mechanism which governs hyperglycemia and glycosuria is not so simple as has been hitherto supposed. Part of the free sugar in excess in the blood can go more or less rapidly into combination without being lost to the organism, the surplus only passing into the urine.-R. Anthony and L. Gain: The development of the skeleton of the posterior extremity of the penguin.--Armand Dehorne : New researches on maturation mitosis in Sabellaria spinulosa.-André Mayer and Georges Schaeffer: The composition of the tissues in non-volatile fatty acids and in cholesterol and the possible existence of a "lipocvtic constant." $-\mathrm{Em}$. Bourquelot, $H$. Hérissey, and $M$. Bridel : The biological synthesis of the glucosides of alcohols ( $\alpha$-glucosides) with the aid of $\alpha$-glucosidase The destruction of the $\alpha$-glucosidase in strongly alcoholic medium.-Fernand Meunier: The frequent asymmetry of the elytra in Blattidæ of the Coal Measures of Commentry (Allier), and the phylogeny of the groups.-Jules Welsch: The primary dunes of Gascony, and an explanation of their formation.

\section{BOOKS RECEIVED.}

Vergleichende Physiologie wirbelloser Tiere. By Prof. H. Jordan. Erster Band. Pp. xxii +738 . (Jena: G. Fischer.) 24 marks.

One Hundred Simple and Exact Mathematical Proofs that the Valencies of Carbon are Unequal. By H. Collins. Pp. Iog. (London: Morton and Burt, Ltd.)

Les Atomes. By Prof. J. Perrin. Pp. xvi +296 . (Paris: F. Alcan.) 3.50 francs.

The Observer's Handbook for 19r3. Pp. 72. (Toronto : Royal Astronomical Society of Canada.)

Annuario Publicado pelo Observatorio Nacional do Rio de Janeiro. Para o Anno de I9I3. Anno xxix. Pp. vii $+349+$ plate. (Rio de Janeiro.)

The Honey-Star. By T. Edwardes. Pp. viii +344 . (London: Hutchinson and Co.) $6 s$.

The Bradshaw Lecture on the Biology of Tumours. by Dr. C. M. Moullin. Pp. 39. (London: H. K. Lewis.) 2s, net.

Our Vanishing Wild Life: its Extermination and Preservation. By Dr. W. T. Hornaday. Pp. xv.+ 4II. (New York: Charles Scribner's Sons.) I.50 dollars.

Trees in Winter : their Study, Planting, Care, and Identification. By Drs. A. F. Blakeslee and C. D. Jarvis. Pp. 446. (New York: The Macmillan Co.; London: Macmillan and Co., Ltd.) 8s. $6 d$. net.

"Red Books" of the British Fire Prevention Committee. No. 176 , Fire Tests with Celluloid Substitutes. The Committee's Report. Pp. 31. (London: British Fire Prevention Committee.)

The Fate of Empires: being an Inquiry into the Stability of Civilisation. By Dr. A. J. Hubbard. Pp. $\mathrm{xx}+220$. (London: Longmans and Co.) $6 s .6 d$ net.

Luftelektrizität. By Dr. K. Kähler. Pp. I5I. (Berlin and Leipzig: G. J. Goschen.) 90 pfennigs.

Health through Diet. By K. G. Haig, with the advice and assistance of Dr. A. Haig. Pp. $\mathrm{x}+227$. (London: Methuen and Co., Ltd.) 3s. 6d. net.

Diptera Danica: Genera and Species of Flies hitherto Found in Denmark. By W. Lundbeck. Part iv., Dolichopodidæ. Pp. 415. (Copenhagen : G. E. C. Gad; London: W. Wesley and Son.)

Das Wissen der Gegenwart in Mathematik und Naturwissenschaft. By E. Picard. German translation by $\mathrm{F}$. and L. Lindemann. Pp. iv +292. (Leipzig and Berlin: B. G. Teubner.) 6 marks.

British Birds' Nests: How, Where, and When to Find and Identify Them. By R. Kearton. Revised and enlarged edition. Pp. $x i i+520+$ plates. (London : Cassell and Co., Ltd.) I4s. net.

The Cambridge Manuals of Science and Literature : The Physical Basis of Music. By Dr, A. Wood. Pp. 163 . The Story of a Loaf of Bread. By Prof. T. B. Wood. Pp. vi+140. The Modern Warship. By E. L. Attwood. Pp. I46. The Earth: its Shape Size, Weight, and Spin. By Prof. J. H. Poynting. Pp. 14I. The Atmosphere. By A. J. Berry. Pp. 146. (Cambridge University Press.) Each is. net.

Handwörterbuch der Naturwissenschaften. By E. Korschelt and others. Lief 35-37. (Jena: G. Fischer.) 2.50 marks each Lief. 